\title{
Penerapan Metoda Superimposisi pada Desain Public Space untuk Meningkatkan Apresiasi Masyarakat Urban terhadap Alam
}

\author{
Husna Abharina Mulyani dan Wahyu Setyawan \\ Jl. Arief Rahman Hakim, Surabaya 60111 \\ E-mail:wahyu_s@arch.its.ac.id
}

Jurusan Arsitektur, Fakultas Teknik Sipil dan Perancangan, Institut Teknologi Sepuluh Nopember

\begin{abstract}
Abstrak-Isu kerusakan alam dan rendahnya apresiasi masyarakat urban terhadap alam urban yang ada, maka disimpulkan bahwa perlu adanya sebuah arsitektur yang ditujukan untuk merubah persepsi masyarakat terhadap alam, dimana persepsi tersebut akhir-akhir ini makin dikaburkan karena terjadi pemisahan antar alam dan manusia. Dengan menggunakan pendekatan biophilic maka didapatkan rincianrincian program yang dapat meningkatkan keterikatan antara masyarakat urban dan alam yang selanjutnya, diiringi oleh metode superimposisi, mampu menjadikan ruang publik ini terlepas dari identitas program utama yang dimaksudkan oleh perancang namun menyatu secara bersamaan dengan program-program lainnya untuk membangun identitas program utama tanpa harus meneksklusifkan dirinya. Sehingga, ruang publik dengan tujuan meningkatkan apresiasi masyarakat terhadap alam dapat tercapai.
\end{abstract}

Kata Kunci- kerusakan alam, biophilic, memorial, superimposisi, public space.

\section{PENDAHULUAN}

$\mathrm{K}$ etika sebuah arsitektur berada dalam sebuah lahan, arsitektur tersebut selalu dilihat sebagai sebuah struktur yang stabil, yang kenyataannya sebaliknya. Sesuai dengan pernyataan Bernard Tschumi dalam salah satu bukunya bahwa arsitektur merupakan struktur yang tidak pernah stabil, selalu berada di ambang perubahan, hal ini tentunya bukanlah menyiratkan bahwa tidak ada suatu kestabilan dalam bangunan solid seperti struktur dan sebagainya, namun perbincangan arsitektur sebagai sesuatu yang stabil dengan program, event dan makna yang sepertinya tidak memiliki celah untuk perubahan, merupakan salah satu cara untuk melupakan dampak kehadiran pengguna dan perpindahannya dalam arsitekturnya.

Untuk memperkecil cakupan pembahasan, maka pembatasan isu difokuskan terhadap topik kerusakan alam. Seperti yang selama ini kita kenal, alam selalu diidentikkan dengan hutan belantara yang berada di area pedalaman tersebar diseluruh penjuru dunia yang jika dipersingkat kesimpulannya adalah suatu keadaan yang sangat berbeda dengan apa yang kita tinggali saat ini, yaitu kawasan urban. Definisi tersebut tentunya tidak ada yang salah, namun pemisahan tersebut menjadikan manusia memiliki pemikiran bahwa manusia bukanlah bagian dari alam, dan

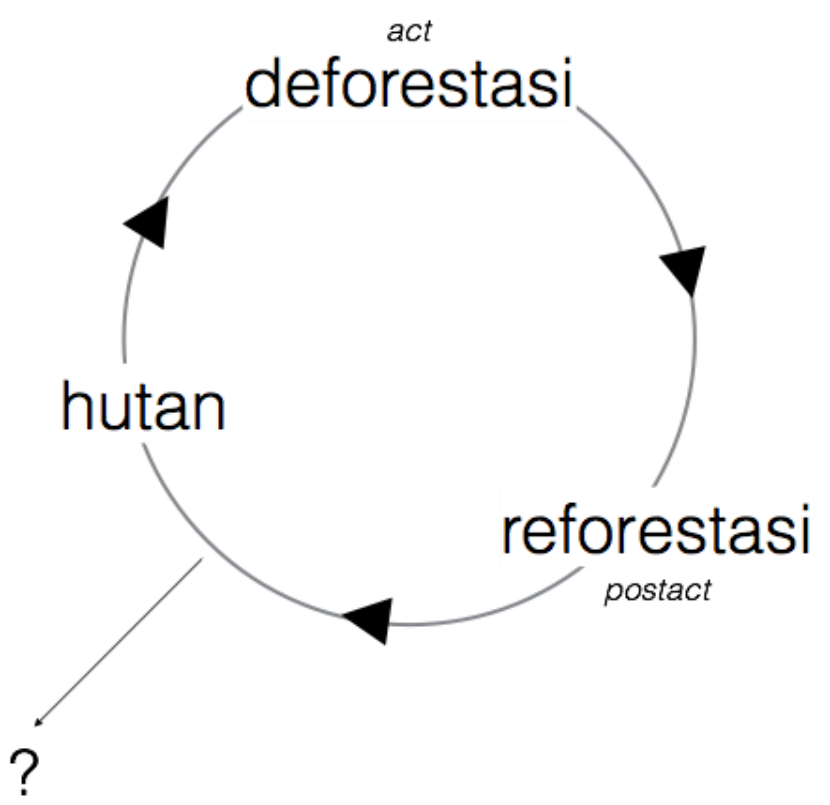

Gambar 1. Diagram Terjadinya Perputaran Deforestasi

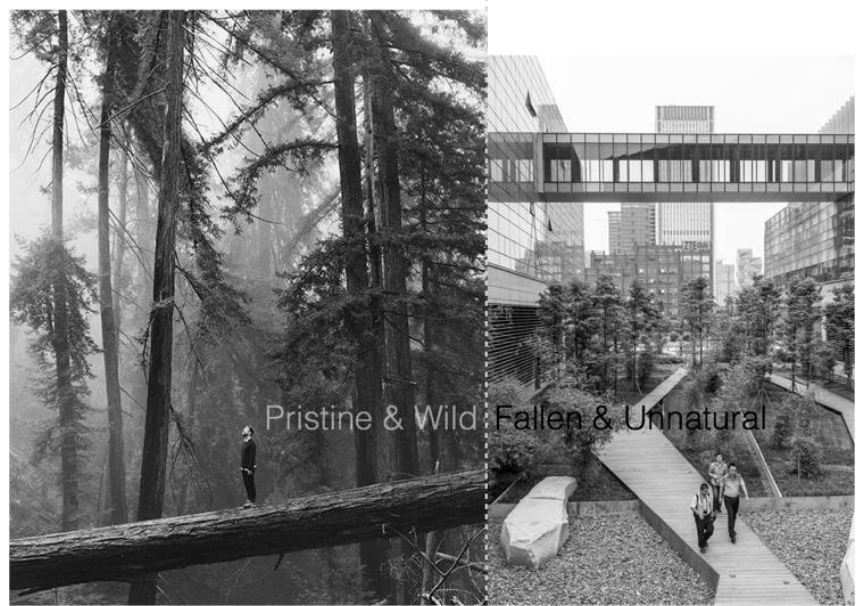

Gambar 2. Persepsi Masyarakat Urban terhadap Alam di Wilderness dan Alam di Urban 
bahwa alam tidaklah diciptakan untuk mereka dan anggapan-anggapan bahwa kehadiran manusia hanya bisa membawa dampak buruk terhadap alam. Pemahaman ini pada akhirnya tidak akan memberi keluaran baik terhadap alam, dan akan meningkatkan laju kerusakan alam, Cronnon (1995) dikarenakan hal tersebut memicu manusia terhadap aktivitas perusakan[1]. Aktivitas itu sendiri terjadi dikarenakan pemisahan mendukung hilangnya kesempatan manusia untuk memahami posisinya sebagai makhluk yang beretika dan honourable di alam itu sendiri. (Gambar 1)

Dengan pernyataan tersebut, maka yang perlu dilakukan adalah membatasi desain dalam kawasan urban, hal ini dikarenakan pemisahan antara alam dan manusia sangat terasa jelas di kawasan-kawasan urban, sehingga menurut pengamatan saya, masyarakat urban juga cenderung memiliki tingkat apresiasi yang rendah terhadap alam yang ada disekitarnya. Pemisahan itu sendiri sebenarnya tidak diadakan dengan adanya batasan fisik terhadap alam dan masyarakat urban, namun masyarakat urban sendirilah yang menciptakan batas tersebut.

Mengacu pada Problem Seeking [2] oleh William M. Pena didapatkan goals, facts, concepts, needs dan problem yang dapat membantu dalam proses perancangan seperti yang terlihat pada gambar 3 .

\section{PENDEKATAN DESAIN}

Biophilic dipilih sebagai pendekatan dalam desain ini baik untuk menghasilkan solusi-solusi dari permasalahan desain yang telah ditentukan. Di akhir, pendekatan ini membantu untuk menghasilkan program-program dalam rancangan ini sehingga rancangan dapat mencapai tujuannya dengan baik.

Seperti yang telah dijelaskan pada bab sebelumnya, banyak peneliti mensetujui adanya kesalahan dalam memandang keterkaitan antara alam dan manusia yang menyebabkan meningkatnya kerusakan hutan. Begitupula dengan World Commision on Protected Area (WCPA) menyatakan ada 11 intangible values yang dimiliki oleh protected areas, yaitu: Recreational, Therapeutic, Spiritual, Cultural, Identity, Existence, Artistic, Aesthetic, Educational, Scientific Research dan Peace values yang kemudian dapat diaplikasikan dalam upaya restorasi alam [3]. Kecenderungan masyarakat Indonesia yang dikenal dengan budaya keagamaannya menjadikan fokus dari value dari alam tersebut terletak pada spiritual values. Sehingga, pada akhirnya ditentukan keseluruhan arsitektur ini merupakan kombinasi dari berbagai macam aktivitas dari kontemplasi itu sendiri.

Selanjutnya, biophilic dipilih berdasarkan kemampuannya untuk menjabarkan hubungan antara alam, manusia, arsitektur dan urban[4]. Tiap design pattern yang dimiliki oleh biophilic menggambarkan kedekatan dan dampak psikologis yang akan dialami oleh manusia yang merasakannya. Melalui pengamatan, maka dari 14 pattern ini memiliki tingkat keberhasilan kontemplasi yang lebih tinggi daripada yang lain sehingga membentuk rincian fasilitas-fasilitas tertentu (Gambar 4).

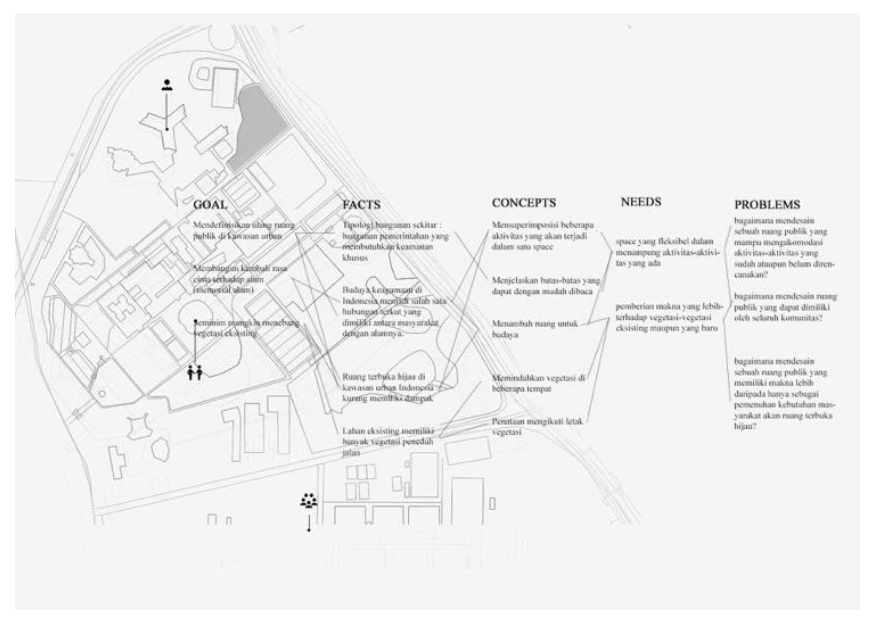

Gambar 3. Hubungan antara Goal, Fact, Concept, Need, Problem dalam rancangan

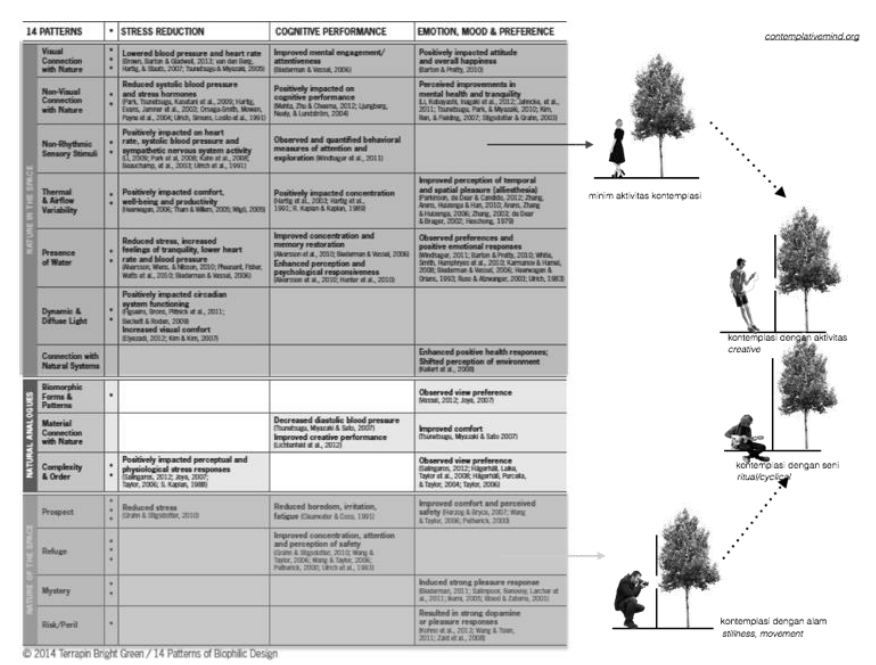

Gambar 4. 14 Pattern Biophilic dan Program Kontemplasi

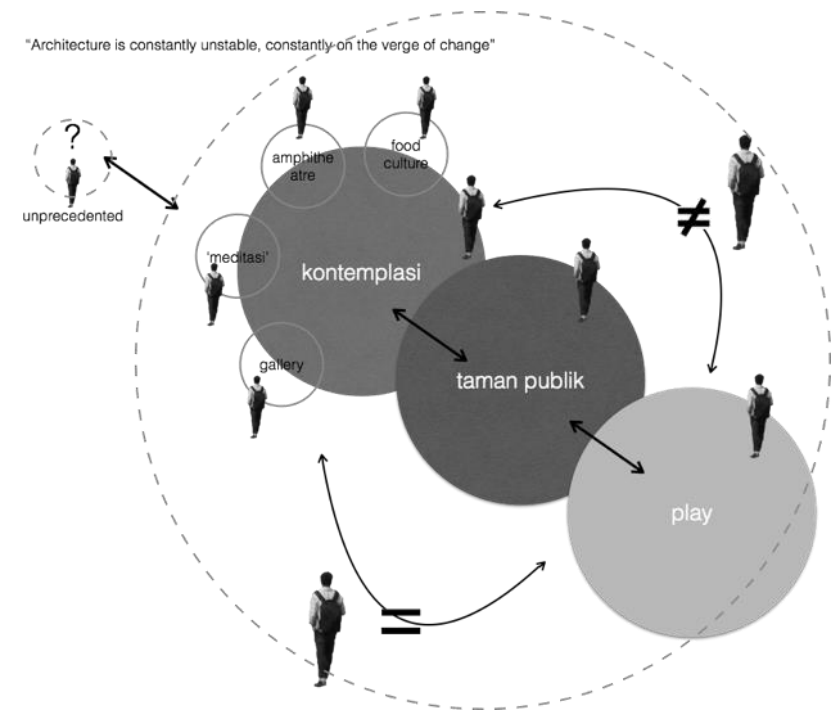

Gambar 5. Persepsi akan kegunaan arsitektur yang muncul dalam rancangan 


\section{METODA DESAIN}

Dengan didapatkannya program dan kebutuhankebutuhan ruang melalui pendekatan dan juga anjurananjuran dalam perencaan ruang publik, maka dibutuhkan suatu metoda yang dapat menjamin keseluruhan program, fasilitas yang disediakan dalam rancangan dapat berjalan dengan baik tanpa ada satu yang lebih unggul dibanding yang lain, maupun mendominasi. Hal tersebut tentunya penting dalam perancangan ruang publik sehingga ruang tersebut dapat terhindar dari dominasi satu kelompok pengguna saja.

Penggunaan metode superimposisi yang dipopulerkan oleh Bernard Tschumi melalui bukunya Architecture and Disjunction dirasa mampu mengantar rancangan ini untuk dapat mencapai tujuannya [5]. Secara mendasar metode superimposisi ini adalah menggabungkan beberapa layer yang berbeda satu sama lainnya ke dalam satu bidang datang. Dirancangan ini, proses dimulai dengan menyatukan tiga layer dasar yang merupakan hubungan antara space dan event, yaitu indifference, reciprocity dan conflict, masingmasing dijelaskan pada gambar 6 dan 7 sehingga terjadi konflik antara program satu dan lainnya. Tiap layer disini memiliki makna dan tujuan sendiri-sendiri di dalam proses melahirkan suatu event dalam ruang.

Layer indifference merupakan layer utama dimana ia menjadi base perletakan program dari layer-layer lainnya. Layer ini memiliki program sebagai ruang publik dimana event dan space yang terjadi di fasilitas tersebut tidak terikat satu sama lainnya. Indifference ini kemudian mampu memberikan statement yang mampu mendukung eventevent yang terjadi ketika pengguna mengalami konflikkonflik dalam program.

Karena tidak adanya hubungan yang mengikat antara space dan event, maka terdapat dua kemungkinan hubungan yang mampu diciptakan yaitu saling bergantung, umumnya merupakan ide dasar dari perancang (reciprocity) dan yang menimbulkan konflik (conflict). Reciprocity yang lebih diindikasikan menjadi tujuan utama, akhirnya difokuskan pada program-program kontemplasi sedangkan conflict diadakan untuk menambah beragamnya narasi yang ditawarkan dalam penggunaan fasilitas tersebut yang diwujudkan dalam program playground. Program ini mampu mengantisipasi 'penyalahgunaan' dalam rancangan sehingga rancangan dapat beradaptasi terhadap event-event baru yang tidak dipresedenkan sebelumnya.

\section{HASIL DAN EKSPLORASI}

Penerapan metode terhadap eksplorasi pendekatan menghasilkan sebuah rancangan yang mampu meningkatkan apresiasi masyarakat urban terhadap alam dengan pemasukan unsur kontemplasi yang berhubungan dengan budaya spiritual yang kerap dilakukan oleh masyarakat Indonesia dengan alam yang ada di sekitarnya.

Didorong oleh faktor kondisi lahan eksisting yang memiliki vegetasi yang rimbun dan juga keberadaan di kawasan DPR/MPR RI yang memiliki keinginan untuk menjadi pusat visual dari seluruh kegiatan di kawasan tersebut [6], maka menjadi tugas perancang untuk

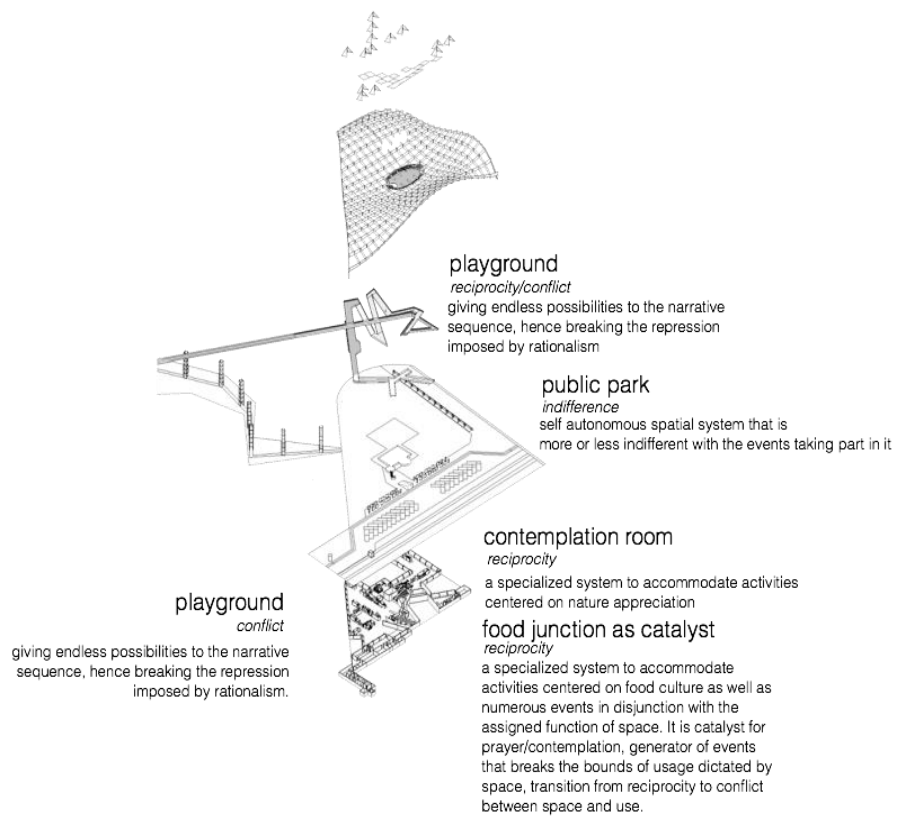

Gambar 6. Hubungan antara space dan event dalam rancangan

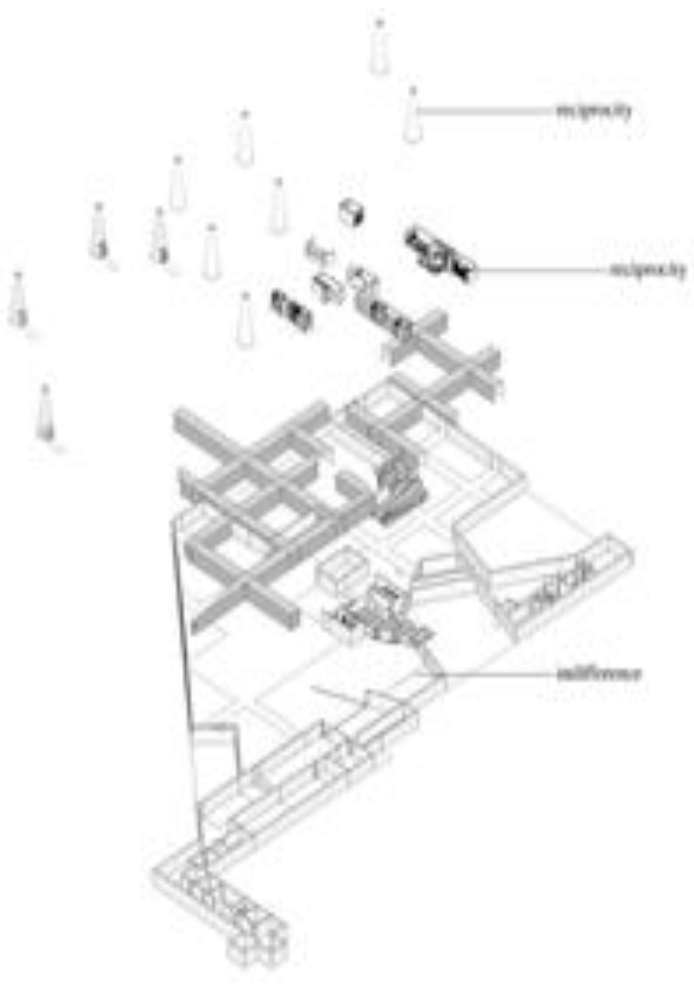

Gambar 7. Hubungan antara space dan event dalam rancangan 
mempertahankan kondisi eksisting dan mewujudkan citacita kawasan tersebut, sehingga program dibagi ke lantai ground yaitu lahan eksisting dan basement, yang ditujukan untuk mengurangi intervensi lahan eksisting serta menyediakan akses visual yang cukup untuk bangunanbangunan pemerintahan. Lantai basement menampung hampir keseluruhan program utama kontemplasi dari arsitektur ini. Ketiga hubungan ruang dan event yang terjadi dalam rancangan ini pun dapat dilihat dari basement. Sedangkan lantai ground di rancangan ini difokuskan untuk kontemplasi yang langsung bersentuhan dengan alam.

Dengan begitu maka penataan denah lantai basement (Gambar 8) akan menunjukkan kekompleksitasan program dengan menawarkan skema dari tiga tingkat hubungan antara space, event dan movement seperti yang sudah dibahas sebelumnya. Baik event dan movement disini berdiri sendiri dari arsitekturnya sehingga rancangan ini dapat dikatakan tidak ditentukan oleh kehati-hatian perancang, pola pikir yang sistematis atau bahkan usaha untuk memperbesar 'narasi'. Sebaliknya, seperti yang dikatakan Tschumi sendiri, "occasional pleasure of unions and long lasting pain of collisions between space, events and movements that makes the reality."

Maka dari itu, hasil rancangan dapat dipahami sebagai dalam sistem untuk mematerialisasikan konsep. Ini berarti bahwa mungkin tidak ada yang sederhana dalam bentuk pengoperasian arsitektur ini, dan hanya penggambaran ekspresi dari konsep. Untuk memperjelas hubungan ini, perancang menambahkan tiga sekuens (Gambar 9). Sekuens pertama merupakan denah dilengkapi notasi dari konsep. Sekuens kedua merupakan identitas awal yang dimiliki ruang-ruang dalam rancangan ini tanpa adanya intervensi oleh event maupun movement. Sedangkan di sekuens ketiga adalah bagaimana ketika ruangan itu digunakan. Dengan superimposisi ketiga sekuens, perancang mencoba membuktikan bahwa ketidakpastian yang dimiliki antar ruang dan penggunaanya dapat membangkitkan apresiasi terhadap alam dengan stimulasi dari kontemplasi.

Aktivitas kontemplasi yang bersentuhan dengan alam langsung pada lantai dasar dioptimalkan dengan usaha untuk membingkai vegetasi-vegetasi eksisting pada lahan. Tujuan dari pembingkaian tersebut yaitu untuk memfokuskan arah pandang masyarakat urban, hal ini didasari karena tingginya aktivitas yang dimilika masyarakat urban menyebabkan masyarakat urban kurang peka terhadap sekeliling kecuali jika ada yang menarik perhatiannya. Pembingkaian ini dilakukan dengan berbagai cara yaitu dengan adanya furniture yang dapat digunakan untuk rebahan sehingga pembingkaian yang terjadi pada atap dengan grid $5 \mathrm{mx} 5 \mathrm{~m}$ dapat dinikmati dengan sudut pandang baru. Selain itu, adanya jembatan yang mengarahkan pengunjung ke letak vegetasi-vegetasi yang memiliki makna lebih seperti memiliki bunga yang cantik dan juga vegetasi yang sudah sangat tua juga merupakan upaya pembingkaian sehingga tercipta kontemplasi yang diinginkan.

Selanjutnya, keseluruhan desain dapat disebut sebagai sebuah memorial terhadap alam yang keberadaannya didukung oleh museum kehutanan yang terletak pada kawasan Kementrian Kehutanan tepatnya di Gedung Manggala Wanabakti. Disini, memorial alam kemudian menjadi perluasan dari museum tersebut yang dapat diibaratkan sebagai sebuah lobby, ruang informasi terbuka untuk publik yang dapat menarik pengunjung menuju museum.

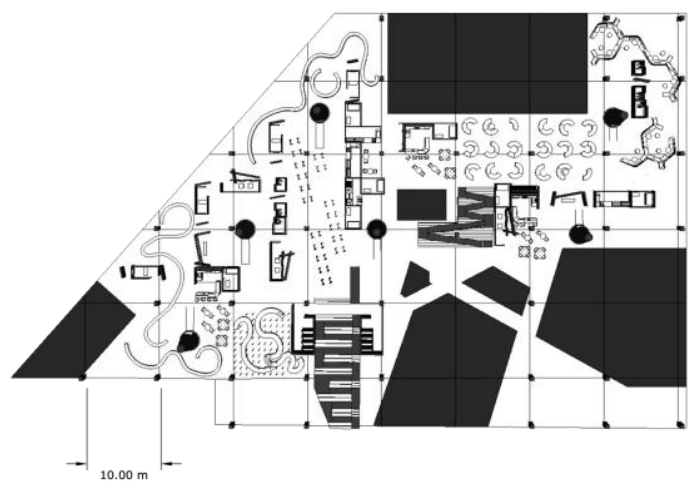

Gambar 8. Konsep Denah Basement
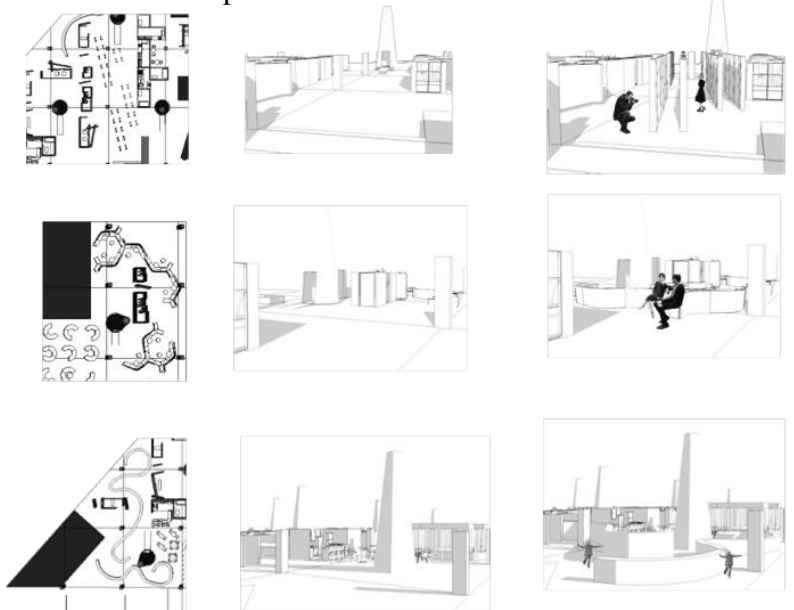

Gambar 9. Sequence pada Basement

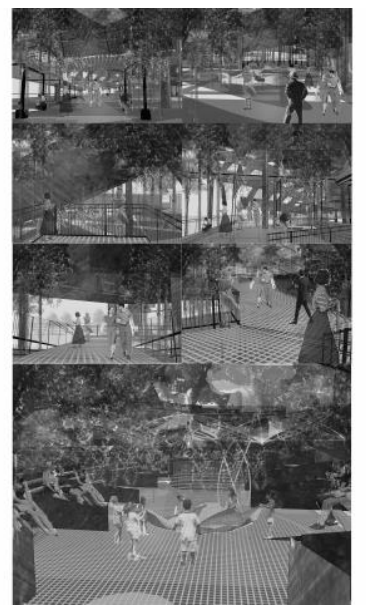

Gambar 10. Sequence pada Taman dan Jembatan Kontemplasi

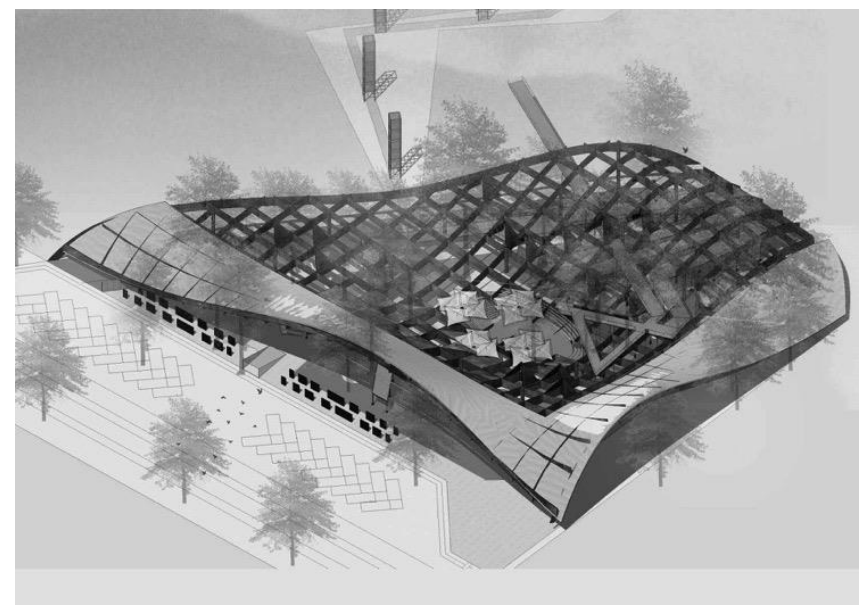

Gambar 14. Perspektif Eksterior 


\section{KESIMPULAN}

Dengan mengaplikasikan metode superimposisi yang dikeluarkan oleh Bernard Tschumi, arsitektur yang hadir akan 99\%-nya merupakan konseptual dimana konseptual ini menjadikan arsitektur lebih terbuka dan bebas untuk diinterpretasikan fungsinya oleh pengunjung. Ketiga hubugan ruang, yaitu indifference, reciprocity dan juga conflict di arsitektur ini saling berkaitan untuk memberikan experience baru terhadap masyarakt urban dalam mengapresiasi alam.

Tentunya tidak seluruh RTH dapat didesain seperti ini, RTH ini difungsikan sebagai langkah pertama untuk penyelamatan hutan di Indonesia. Hal ini tidak berarti diseluruh kawasan perlu adanya RTH yang sama seperti yang didesain ini. Begitu pula RTH seperti ini tidak dapat diaplikasikan dikawasan non urban karena cara memandang hubungan antara arsitektur, alam dan manusianya berbeda satu sama lain.

Akhir kata, dalam mendesain sebuah arsitektur untuk menambah experience, edukasi dan pemahaman mengenai pentingnya alam tidak dapat dihadirkan hanya dengan penataran sejumlah objek, namun lebih dicondongkan untuk memperkaya pengalaman sehingga terjalin kembali hubungan yang sebelumnya sempat hilang diantara kaum urban dan alamnya.

\section{DAFTAR PUSTAKA}

[1] W. Cronnon, "The Trouble with Wilderness; or, Getting Back to the Wrong Nature," in Uncommon Ground: Rethinking the Human Place in Nature, W. Cronnon, Ed. New York: W. W. Norton \& Co. (1995) 69-90.

[2] W. M. Pena, S.A. Parshall, Problem Seeking: An Architectural Programing Primer. Hoboken, NJ: Wiley (2012)

[3] D. Harmon, "Intangible Values of Protected Area: What are They? Why do They Matter?," The George Wright Forum, Vol. 21 No. 2, (2004) 9-22.

[4] W. Browning, C. Ryan, J. Clancy, 14 Patterns of Biophilic Design. New York: Terrapin Bright Green llc (2014)

[5] B. Tschumi, Architecture and Disjunction. Massachusetts: The MIT Press (1994)

[6] Ikatan Arsirek Indonesia. Gedung MPR/DPR RI: Sejarah dan Perkembangannya. Jakarta: Badan Sistem Informasi Arsitektur Ikatan Arsitek Indonesia. 